\title{
COMPARATIVE PHYTOCHEMICAL EVALUATION IN SEVERAL ACHILLEA SPECIES FROM ROMANIA
}

\author{
MIHAELA POPOVICI ${ }^{1}$, GHEORGHE COLDEA $^{2}$, ANA COSTE $^{2 *}$, CARMEN POP $^{1}$, MIRCEA $^{2}$ \\ TĂMAȘ ${ }^{1}$ \\ ${ }^{I}$ Faculty of Pharmacy, University of Medicine and Pharmacy "Iuliu Haţieganu”, 12 I. Creangă Street, 400010, Cluj-Napoca, \\ Romania \\ ${ }^{2}$ Institute of Biological Research Cluj-Napoca, branch of NIRDBS, 48 Republicii Street, 400015, Cluj-Napoca, Romania
}

*corresponding author: ana.coste@icbcluj.ro

Manuscript received: December 2020

\begin{abstract}
The aim of our study was to perform a comparative phytochemical evaluation in four Achillea species, including two subspecies, from the Romanian spontaneous flora. Essential oils, flavonoids and polyphenolcarboxilic acids were determined by chromatographic and spectrophotometric methods. Essential oil content varied between $0.24-0.40 \%$, but only Achillea millefolium oil complied with the pharmacopoeial requirements regarding the chamazulene content. Amongst the other taxa, only Achillea stricta exhibited low amounts of chamazulene (2.41\%). Overall, average content of flavonoids and phenolcarboxilic acids were registered in our taxa, with apigenin and luteolin as main flavonoids. All the investigated taxa contained clorogenic acid as well as caffeic acid but only in its esterified form. Based on essential oil composition, two infraspecific chemical taxa, Achillea distans subspecies distans and alpina, were first described. This is also the first record of the chemical composition of the essential oil in Achillea nobilis ssp. neilreichii.
\end{abstract}

\section{Rezumat}

Studiul constă în investigarea fitochimică a patru specii de Achillea, incluzând două subspecii, din flora spontană a României. Uleiurile volatile, flavonoidele și acizii polifenolcarboxilici au fost determinaţi prin metode cromatografice și spectrofotometrice. Conţinutul de ulei volatil a variat între $0.24-0.40 \%$, dar numai specia Achillea millefolium a prezentat un conținut de azulene conform cerinţelor compendiale. Acest compus a mai fost identificat in cantitate foarte redusă (2.41\%) doar la specia Achillea stricta. Conținutul de flavonoide și acizi polifenolcarboxilici poate fi apreciat ca un conținut mediu, flavonoidele reprezentative fiind apigenina și luteolina. În toate speciile a fost identificat acidul clorogenic, iar acidul cafeic doar sub formă esterificată. Pe baza compoziției uleiului volatil au fost descriși pentru prima dată doi taxoni chimici infraspecifici aparținând celor două subspecii de Achillea distans. Compoziţia chimică a uleiului esenţial al speciei Achillea nobilis ssp. neilreichii este raportată pentru prima dată.

Keywords: Achillea, essential oils, total flavonoids, phenolcarboxilic acids

\section{Introduction}

The genus Achillea, generally known as "yarrow", belongs to the richest and youngest evolutionary genera of the Asteraceae family [28]. About 140 perennial herbaceous species with worldwide distribution have been recognized in this genus [36]. Numerous species of the genus have been used traditionally as antibacterial, anti-inflammatory, vermifuge, analgesic and expectorant etc. $[4,24,31]$. Its richness in bioactive compounds has made this genus a promising candidate for future research and potential development of new drugs [16]. There are still numerous studies investigating the secondary metabolites of Achillea species known to be rich mainly in essential oils, sesquiterpene lactones, diterpenes, triterpenes, lignans, flavonoids and phenolic acids besides some other groups of compounds such as amino acids, fatty acids, alkane and inulin $[3,12,20,36]$.
In the Flora of Romania, the genus Achillea is represented by 24 species and 18 Achillea hybrids [28]. Among these, Achillea millefolium is the only recognised medicinal species registered in the Romanian Pharmacopoeia X- ${ }^{\text {th }}$ edition (FR X) [38]. In this species, the whole aerial parts (Millefolii herba) or only the inflorescences (Millefolii flos) are used. Its pharmacological actions arise from various groups of compounds such as chamazulene and prochamazulenes (anti-inflammatory), betonicine (haemostatic), flavonoids, azulenes (spasmolytic) [26]. The most important compound in the oil is chamazulene [20], while among phenolic compounds, caffeic acid has both phytoterapeutic and chemotaxonomical importance [21, 25, 30, 32, 35].

In this context our purpose was to investigate the potential use as medicinal species of 5 Achillea taxa from Romania including: Achillea millefolium L., Achillea stricta Gremli, Achillea nobilis L. ssp. 
neilreichii (A. Kern.) Velen., along with an alpine species Achillea distans Willd. and its two subspecies Achillea distans ssp. distans, with white ligulate flowers and Achillea distans ssp. alpina (Rochel) Soo., with red ligulate flowers. We performed comparative qualitative and quantitative phytochemical investigation in the above-mentioned taxa, mainly focusing on: essential oils, flavonoids and polyphenolcarboxilic acids, including caffeic acid.

\section{Materials and Methods}

Achillea plants were harvested from their natural habitats during flowering period (August) from their collection's sites (Table I).

Table I

The Achillea species investigated in this study and their collection sites

\begin{tabular}{|c|c|l|l|}
\hline No & Abbreviations & \multicolumn{1}{|c|}{ Species } & \multicolumn{1}{c|}{ Collection sites } \\
\hline 1 & $A M$ & Achillea millefolium & Stoboru (Sălaj County, Romania) \\
\hline 2 & $A S$ & Achilllea stricta & nearby Tarnița Lake (Cluj County, Romania) \\
\hline 3 & $A D$ & Achillea distans ssp. distans & nearby Iezer Lake (Rodnei Mountains, Romania) \\
\hline 4 & $A A$ & Achillea distans ssp. alpina & nearby Iezer Lake (Rodnei Mountains, Romania) \\
\hline 5 & $A N$ & Achillea nobilis ssp. neilreichii & Suplacul de Barcău (Bihor County, Romania) \\
\hline
\end{tabular}

The plant material consisting of inflorescences has been dried at $25^{\circ} \mathrm{C}$, ground into a fine powder and subjected to the investigation of bioactive compounds. Gas-chromatographic analysis. The extraction and quantification of the essential oils from dried inflorescences was made in a Neo-Clevenger apparatus [38] and analysed further by GS-MS. The gaschromatographic analysis has been performed after the method described by Popovici MP et al. [25]. Wiley Library was used as reference database.

Spectrophotometric method. Quantitative determination of the total flavonoids and of polyphenocarboxylic acids was done by the spectrophotometric method indicated in the FR X [38] and expressed as g rutin per $100 \mathrm{~g}$ dry weight and polyphenolcarboxylic acids were determined with Arnow reagent and expressed as g caffeic acid per $100 \mathrm{~g}$ dry weight.

HPLC analysis. The qualitative analysis for both classes of compounds was performed by the HPLC method described by Popovici MP et al. [23]. For the preparation of un-hydrolysed samples, the plant material was extracted at $60^{\circ} \mathrm{C}$ on a water bath with $70 \%$ ethanol for 30 minutes. The supernatant was recovered after filtration. For the preparation of hydrolysed samples, the supernatant previously obtained was submitted to acid hydrolysis $(\mathrm{HCl}$, $2 \mathrm{~N}$ ) on a water bath at $80^{\circ} \mathrm{C}$ for 60 minutes.

Statistical analysis. The statistical significance of data was determined by one-way analysis of variance (ANOVA) followed by Tukey's honestly significant difference (HSD) test $(\mathrm{P} \leq 0.05)$ using SPSS program ver. 17.0 (SPSS Inc., Chicago, USA) [29].

\section{Results and Discussion}

The rapidly growing demand for medicinal plants correlated with habitat loss, are putting pressure on many species. Thus, we face not only to lose known medicinal plants but also plants with until-nowunknown properties and potential sources of health promoting compounds [11]. Yarrow plants have been shown to contain significant level of essential oils as well as flavonoids and phenolic acids with proven role as health-promoting chemicals showing a broadspectrum inhibitory activity over micro-organisms, as demonstrated by the in vitro tests against several types of human pathogens $[6,33]$. Therefore, exploring the phytochemical profile of lesser-known taxa such as A. distans ssp. alpina and A. nobilis ssp. neilreichii, is important to support their sustainable exploitation for the pharmaceutical industry.

While previous studies were limited to a confined group of specific compounds (only prochamazulenes) [14], or were restricted to a particular taxonomic group of Achillea species [8], our investigations not only contribute to a more complex characterization of volatile oils in 5 different taxa but also to the identification of two infra-specific taxa based on volatile oils composition in A. distans.

In our study, the essential oils content of the investigated Achillea species varied between $0.24-0.40 \mathrm{~mL} / 100 \mathrm{~g}$, without significant differences between them (Table II). The overall essential oil content corresponds to the Romanian Pharmacopoeia requirements [38], as FR X request only a minimal content of essential oils $(0.2 \%)$. According to the European Pharmacopoeia $9^{\text {th }}$ ed. [39], the Achillea millefolium Milefolii herba should contain a minimum of $2 \mathrm{~mL} / \mathrm{kg}$ essential oil (dried drug) and proazulenes, expressed as chamazulene $\left(\mathrm{Cl}_{4} \mathrm{H}_{16} ; \mathrm{Mr} 184.3\right)$ a minimum of 0.02 percent (dried drug). Thus, the differences between the required standards for essential oil and chamazulene content between the Romanian [38] and European [39] Pharmacopoeia may results from the fact that FR X refers to the inflorescences (Millefolii flos) while the European Pharmacopoeia [39] refers to Millefolii herba of Achillea millefolium.

Our results are also in agreement with the essential oil concentrations reported in the existing literature for other Achillea species. Thus, essential oil content was reported to vary between 0.1 to $1.35 \%$ dry weight depending on plant genotype and other conditions $[17,19]$. The azulene content (chamazulene), the most 
important ingredient of the oil, was significantly lower in our species than the minimum $(12 \%$ azulene in the essential oil) required by FR VIII [37] and X [38]. Thus, only A. millefolium oil proved to comply with the Romanian pharmacopoeial requierements $(25.26 \%$ chamazulene in the essential oil), whereas the other species either totally lack this compound or exhibit very low concentrations of chamazulene $(2.41 \%$ in A. stricta) (Table II). These results prove that only the investigated A. millefolium inflorescences might be successfully employed to obtain extracts with medicinal value. According to the existing literature, azulenogenic compounds are characteristic to only several members of the Achillea genus, in particular A. asplenifolia Vent., A. roseo-alba Ehrend., and A. collina Becker, while other have been reported to be free of azulenes such as A. nobilis L. var. ochroleuca Boiss and A. distans W. et K. [20]. However, many contradictions concerning the chamazulene content of Achillea species have been reported, mainly explained by the genetic background (ploidy level) and the differences in isolation methods. Thus, the chemical composition of the yarrow oil seems to depend a lot on the number of chromosomes. Diploid and tetraploid

plants were reported to contain mainly proazulene sesquiterpenes, which are transformed, as a result of hydro-distillation, mainly to chamazulene (up to $25 \%$ ); while the main substances found in hexaploid plants were camphor (18\%), sabinene (12\%), 1,8cineole (10\%), etc., and the main substance found in octaploid plants was linalool 2 [26]. The essential oil of tetraploid Achillea species has been reported to contain up to $50 \%$ chamazulenes while diploid, hexaploid and octaploid species, may contain little to no chamazulenes $[10,18,20,22]$. Our results are thus endorsed by the ploidy levels reported in literature for these species. Thus, species as A. nobilis reported as diploid and $A$. distans reported as hexaploid [1, 7, 9] are lacking chamazulene, while A. stricta reported as octoploid [1] contains low amounts of this compound. For A. millefolium, four ploidy levels have been detected (diploid, tetraploid, hexaploid and octoploid) $[7,15]$. Considering these aspects we speculate that our chamazulene rich $(25.26 \%)$ population of $A$. millefolium might be tetraploid. The first investigations regarding the content in the major proazulene (prochamazulene) of Achillea species from Romania were performed by Kotilla E [14] and Gherase F et al. [8].

Table II

The content in essential oils and chamazulene

\begin{tabular}{|l|c|c|c|}
\hline \multicolumn{1}{|c|}{ Species } & $\begin{array}{c}\text { Essential oil concentration } \\
(\mathbf{m L / 1 0 0} \mathbf{~} \text { dry weight })\end{array}$ & Essential oil colour & $\begin{array}{c}\text { Chamazulene content of the essential oil } \\
(\mathbf{\%})\end{array}$ \\
\hline A. millefolium & $0.40 \pm 0.10^{\mathrm{a}}$ & dark blue & $25.26 \pm 0.25^{\mathrm{a}}$ \\
\hline A. stricta & $0.24 \pm 0.12^{\mathrm{a}}$ & pale blue & $2.41 \pm 0.15^{\mathrm{b}}$ \\
\hline A. nobilis ssp. neilreichii & $0.27 \pm 0.11^{\mathrm{a}}$ & colourless & - \\
\hline A. distans ssp. distans & $0.40 \pm 0.20^{\mathrm{a}}$ & colourless & - \\
\hline A. distans ssp. alpina & $0.25 \pm 0.12^{\mathrm{a}}$ & colourless & - \\
\hline
\end{tabular}

GC-MS analysis in A. millefolium revealed 34 essential oil components with: $\beta$-pinene $(32.11 \%)$, chamazulene $(25.26 \%)$, trans-caryophyllene $(9.15 \%)$, eucalyptol (6.58\%), germacrene D (5.59\%) and $\alpha$-pinene (3.24\%) as major compounds. A. stricta essential oil contained 22 components of which the most predominant were: $\beta$-pinene (13.51\%), eucalyptol (12.92\%), camphor (11.14\%), bornyl acetate (11.11\%), $\alpha$-pinene (4.29\%), trans-caryophyllene (4.25\%) and chamazulene (2.41\%). The A. nobilis ssp. neilreichii oil comprised 48 compounds with five major components: lavandulyl acetate $(2.50 \%)$, geranyl acetate $(3.19 \%)$, caryophyllene oxide $(3.79 \%)$, veridiflorol $(4.09 \%)$, p-cymene $(2.96 \%)$ and valeranone $(1.44 \%)$, while two components remained unidentified with Rt 12.79 (21.20\%) and Rt $13.81(21.27 \%)$. A. distans ssp. distans oil revealed 18 components with the following main compounds: $\alpha$ thujone $(33.31 \%), \beta$-thujone $(25.52 \%)$, sabinene (15.60\%), eucalyptol (9.05\%) and camphor (2.59\%). 36 compounds were separated in A. distans ssp. alpina essential oil and the main components were: eucalyptol (20.97\%), sabinene (6.37\%), $\beta$-fenchol $(5.52 \%)$, camphor $(4.94 \%)$, borneol $(4.48 \%), \beta-$ caryophyllene $(3.00 \%)$, bornyl acetate (2.61\%), valeranone $(2.30 \%), \alpha$-pinene $(1.15 \%)$ and gammaterpinene $(1.01 \%)$.

Regarding the essential oil composition of $A$. distans subspecies, it's important to underline the fact that the two major components $\alpha$ - and $\beta$-thujone (53.83\%) that are present in $A$. distans ssp. distans oil are completely lacking from $A$. distans ssp. alpina. These two subspecies show infra-specific variations in the chemical composition of the essential oil. It was shown that these subspecies also reveal significant morphological differences [30]. The literature survey revealed a high variability of Achillea species essential oil profile [12, 13, 20, 36].

Flavonoid and phenolic compounds were detected at varying concentrations across the analysed species (Table III). Our results show significant differences $(\mathrm{P} \leq 0.05)$ in the total flavonoids content between the analysed species, while no significant differences were registered for polyphenolcarboxylic acids. The inflorescences of the investigated Achillea species contained significant amounts of total flavonoids ranging from $1.48 \%$ in $A$. stricta to $2.93 \%$ in $A$. 
distans ssp. alpina. These values are higher than those previously reported $(0.5-1.8 \%)$ by Gherase F et al. [8] in plant materials of other Achillea species belonging to the $A$. millefolium L. group, while slightly lower than those reported by Benedec D et al., [2] in the same species $A$. distans subsp. alpina flowers (3.31\%) and A. distans ssp. distans extract (3.72\%).

The taxa investigated in our study showed an average content of caffeic acid derivatives varying between $0.25 \%$ in A. stricta and $0.33 \%$ in A. distans ssp. alpina (Table III). Thus, lower amounts of caffeic acid derivatives were registered in our species investigated in the present study compared with those reported for other Achillea species (41.48 mg/g) [3].

Table III

Flavonoids and polyphenolcarboxilic acids content in 5 Achillea taxa

\begin{tabular}{|l|c|c|}
\hline \multicolumn{1}{|c|}{ Species } & Flavonoids (g\% rutin) & Polyphenolcarboxylic acids (g\% caffeic acid) \\
\hline A. millefolium & $1.66 \pm 0.12^{\mathrm{d}}$ & $0.33 \pm 0.14^{\mathrm{a}}$ \\
\hline A. stricta & $1.48 \pm 0.15^{\mathrm{d}}$ & $0.25 \pm 0.12^{\mathrm{a}}$ \\
\hline A. nobilis ssp. neilreichii & $2.13 \pm 0.11^{\mathrm{c}}$ & $0.33 \pm 0.09^{\mathrm{a}}$ \\
\hline A. distans ssp. distans & $2.52 \pm 0.11^{\mathrm{b}}$ & $0.29 \pm 0.10^{\mathrm{a}}$ \\
\hline A. distans ssp. alpina & $2.93 \pm 0.13^{\mathrm{a}}$ & $0.33 \pm 0.11^{\mathrm{a}}$ \\
\hline
\end{tabular}

Labelled columns not connected by the same letter are significantly different at $\mathrm{P} \leq 0.05$, based on a Tukey's honestly significant difference test

Our results demonstrated that all species contained caffeic and chlorogenic acids (Table IV), with the highest concentrations detected in A. distans subspecies and $A$. millefolium. However, caffeic acid was found only in the hydrolysed extracts, meaning that this compound may be found only in the esterified form in the inflorescences of the analysed Achillea species. It is important to underline the significant amount of caffeic acid contained by A. distans ssp. alpina, which is 4 to 10 times higher than in other species (Table IV). This species contains considerable amounts of most of the investigated polyphenolic compounds, with higher or comparable values to A. millefolium. Therefore, we consider this species a good candidate for the production of phenolic compounds.

HPLC qualitative analysis of flavonoids and phenolcarboxilic acids revealed that our Achillea taxa contained mainly apigenin and luteolin glycosides which were also detected as free compounds, except A. nobilis ssp. neilreichii which contains only luteolin derivatives and lack apigenin (Table IV). Our results regarding the composition of the flavonoid complex are in agreement with those previously reported in yarrow flowers [5].

Table IV

Polyphenolic compounds (mg/100 g dry matter) identified in 5 Achillea taxa

\begin{tabular}{|c|c|c|c|c|c|c|c|c|c|c|}
\hline & \multicolumn{2}{|c|}{ A. millefolium } & \multicolumn{2}{|c|}{ A. stricta } & \multicolumn{2}{|c|}{$\begin{array}{l}\text { A. distans ssp. } \\
\text { distans }\end{array}$} & \multicolumn{2}{|c|}{$\begin{array}{l}\text { A. distans ssp. } \\
\text { alpina }\end{array}$} & \multicolumn{2}{|c|}{$\begin{array}{c}\text { A. nobilis ssp. } \\
\text { neilreichii }\end{array}$} \\
\hline & Nh & H & Nh & H & Nh & $\mathbf{H}$ & Nh & H & Nh & $\mathbf{H}$ \\
\hline $\begin{array}{l}\text { Caffeic acid } \\
\mathrm{Rt}=5.9\end{array}$ & - & $\begin{array}{c}63.20 \pm \\
0.26^{\mathrm{d}}\end{array}$ & - & $\begin{array}{c}82.85 \pm \\
0.40^{\mathrm{c}}\end{array}$ & - & $\begin{array}{c}43.15 \pm \\
0.26^{\mathrm{e}}\end{array}$ & - & $\begin{array}{c}410.40 \pm \\
0.26^{\mathrm{a}}\end{array}$ & - & $\begin{array}{c}92.65 \pm \\
0.23^{\mathrm{b}}\end{array}$ \\
\hline $\begin{array}{l}\text { Chlorogenic acid } \\
\mathrm{Rt}=6.6\end{array}$ & $\begin{array}{c}306.95 \pm \\
0.22^{\mathrm{a}}\end{array}$ & $\begin{array}{c}118.25 \pm \\
0.13^{\mathrm{c}}\end{array}$ & $\begin{array}{c}288.10 \pm \\
0.09^{c}\end{array}$ & $\begin{array}{c}140.90 \pm \\
0.36^{\mathrm{b}}\end{array}$ & $\begin{array}{c}231.50 \pm \\
0.34^{\mathrm{d}}\end{array}$ & $\begin{array}{c}109.95 \pm \\
0.11^{\mathrm{d}}\end{array}$ & $\begin{array}{c}231.50 \pm \\
0.13^{\mathrm{d}}\end{array}$ & $\begin{array}{c}91.80 \pm \\
0.18^{\mathrm{e}}\end{array}$ & $\begin{array}{c}299.40 \pm \\
0.20^{\mathrm{b}}\end{array}$ & $\begin{array}{l}157.50 \\
\pm 0.16^{\mathrm{a}}\end{array}$ \\
\hline $\begin{array}{l}\text { Luteoline } \\
\mathrm{Rt}=29.2\end{array}$ & $\begin{array}{c}70.40 \pm \\
0.10^{\mathrm{c}}\end{array}$ & $\begin{array}{c}109.80 \pm \\
0.17^{\mathrm{c}} \\
\end{array}$ & $\begin{array}{l}51.05 \pm \\
0.11^{\mathrm{d}}\end{array}$ & $\begin{array}{c}82.15 \pm \\
0.25^{\mathrm{d}}\end{array}$ & $\begin{array}{c}130.55 \pm \\
0.40^{\mathrm{b}}\end{array}$ & $\begin{array}{c}191.40 \pm \\
0.40^{\mathrm{b}}\end{array}$ & $\begin{array}{c}258.45 \pm \\
0.09^{\mathrm{a}}\end{array}$ & $\begin{array}{c}303.40 \pm \\
0.19^{\mathrm{a}}\end{array}$ & $\begin{array}{c}42.40 \pm \\
0.11^{\mathrm{e}}\end{array}$ & $\begin{array}{c}50.35 \pm \\
0.14^{\mathrm{e}}\end{array}$ \\
\hline $\begin{array}{l}\text { Apigenine } \\
\mathrm{Rt}=33.2\end{array}$ & $\begin{array}{l}72.10 \pm \\
0.17^{\mathrm{b}}\end{array}$ & $\begin{array}{c}161.30 \pm \\
0.16^{\mathrm{a}}\end{array}$ & $\begin{array}{c}47.10 \pm \\
0.10^{\mathrm{d}}\end{array}$ & $\begin{array}{c}97.60 \pm \\
0.26^{\mathrm{d}}\end{array}$ & $\begin{array}{c}48.55 \pm \\
0.39^{\mathrm{c}}\end{array}$ & $\begin{array}{c}107.40 \pm \\
0.19^{\mathrm{c}}\end{array}$ & $\begin{array}{c}77.95 \pm \\
0.28^{\mathrm{a}}\end{array}$ & $\begin{array}{c}158.85 \pm \\
0.23^{\mathrm{b}}\end{array}$ & - & - \\
\hline
\end{tabular}

$\mathrm{Nh}$ - unhydrolysed samples; $\mathrm{H}$ - hydrolysed samples. Labelled rows not connected by the same letter are significantly different at $\mathrm{P} \leq 0.05$, based on a Tukey's honestly significant difference test. $\mathrm{H}$ and $\mathrm{Nh}$ samples were compared separately

To our knowledge, there are no studies reporting polyphenolcarboxilic acids content for Achillea species. Literature data were mainly focused on the characterization of total phenolics content in wild populations of this genus $[2,5]$.

\section{Conclusions}

The phytochemical profile of the investigated Achillea species revealed variable essential oil content (0.24 $0.40 \%$ ). Only A. millefolium oil contained the required chamazulene concentration in accordance with the FRX requirements. The other investigated species completely lacked this type of azulene, except for $A$. stricta which revealed low amounts of this compound $(2.41 \%)$.

The investigated taxa showed an overall average content of total flavonoids and phenolcarboxilic acids. The main flavonoids were apigenin and luteolin, detected in both their free and conjugated forms. All the investigated Achillea species contained chlorogenic acid as well as caffeic acid, but only its esterified form. Based on the essential oil composition we have described for the first time two infra-specific chemical taxa belonging to the $A$. distans subspecies distans and alpina. 


\section{Acknowledgement}

This study was supported partially by the core program BIOSERV 25N/2019 (core program PN2019-2022 BIODIVERS 3) and 22PFE/2018.

\section{Conflict of interest}

The authors declare no conflict of interest.

\section{References}

1. Baltisberger M, Widmer A, Chromosome numbers and karyotypes within the genus Achillea (Asteraceae: Anthemideae). Willdenowia, 2016; 46(1): 121-135.

2. Benedec D, Vlase L, Oniga I, Mot AC, Damian G, Hanganu D, Duma M, Silaghi-Dumitrescu R, Polyphenolic composition, antioxidant and antibacterial activities for two Romanian subspecies of Achillea distans Waldst. Et Kit. Ex Willd. Molecules, 2013; 18(8): 8725-8739.

3. Benedec D, Hanganu D, Oniga I, Filip L, Bischin C, Silaghi-Dumitrescu R, Tiperciuc B, Vlase L, Achillea schurii flowers: chemical, antioxidant, and antimicrobial investigations. Molecules, 2016; 21(8): 1050: 1-12.

4. Benedek B, Gjoncaj N, Saukel J, Kopp B, Distribution of phenolic compounds in Middleeuropean taxa of the Achillea millefolium L. aggregate. Chem Biodivers., 2007; 4(5): 849-857.

5. Benetis R, Radušienè $J$, Janulis V, Variability of phenolic compounds in flowers of Achillea millefolium wild populations in Lithuania. Medicina (Kaunas), 2008; 44(10): 775-781.

6. Burlec AF, Macovei I, Săcărescu A, Corciovă A, Mircea C, Iancu CE, Cioancă O, Hăncianu M, Essential oils in wellness centers: overview on European Union legislation, potential therapeutic effects and toxicity. Farmacia, 2020; 68(6): 992-998.

7. Danihelka J, Rotreklová O, Chromosome numbers within the Achillea millefolium and the A. distans Groups in the Czech Republic and Slovakia. Folia Geobotanica, 2011; 36(2): 163-191.

8. Gherase F, Miron A, Zagnat M, Hăncianu M, Stănescu U, Grigorescu E, Phytocemical investigation regarding the flavonoidic compounds of some species belonging to the Achillea millefolium Group. Rev Med Chir Soc Med Nat Iași, 2004; 108(1): 177-180.

9. Guo YP, Saukel J, Mittermayr R, Ehrendorfer F, AFLP analyses demonstrate genetic divergence, hybridization, and multiple polyploidization in the evolution of Achillea (Asteraceae-Anthemideae). New Phytol., 2005; 166(1): 273-289.

10. Hofmann L, Fritz D, Nitz S, Kollmannsberger H, Drawert F, Essential oil composition of three polyploids in the Achillea millefolium 'complex'. Phytochemistry, 1992; 31(2): 537-542.

11. Holzmeyer L, Hartig AK, Franke K, Brandt W, Muellner-Riehl AN, Wessjohann LA, Schnitzler J, Evaluation of plant sources for antiinfective lead compound discovery by correlating phylogenetic, spatial, and bioactivity data. Proceedings Nat Acad Sci., 2020; 117(22): 12444-12451.

12. Khan M, Khan M, Abdullah MMS, Al-Wahaibi LH, Alkhathlan HZ, Characterization of secondary metabolites of leaf and stem essential oils of Achillea fragrantissima from Central Region of Saudi Arabia. Arab J Chem., 2020; 13(5): 1-20.

13. Konakchiev A, Todorova M, Mikhova B, Vitkova A, Najdenski H, Composition and antimicrobial activity of Achillea distans essential oil. Nat Prod Commun., 2011; 6(6): 905-906.

14. Kotilla E, Presence of prochamazulene in different Achillea species from Republic of Romania. Medical Journal (Tg. Mureş), 1959; 5: 311, (available in Romanian).

15. López-Vinyallonga S, Soriano I, Susanna A, Montserra JM, Roquet C, Garcia-Jacas N, The polyploid series of the Achillea millefolium aggregate in the Iberian Peninsula investigated using microsatellites. PLoS One, 2015; 10(6): e0129861: 1-19.

16. Majid M, Roshan M, Andleeb L, Bhat MI, Achillea millefolium L.: A Promising Health Aid In Modern Pharmacology. IJARSE, 2018; 7(4): 2167-2182.

17. Mohammadhosseini M, Sarker SD, Akbarzadeh A, Chemical composition of the essential oils and extracts of Achillea species and their biological activities: A review. J Ethnopharmacol., 2017; 199: 257-315.

18. Németh É, Bernáth J, Héthelyi É, Chemotypes and their stability in Achillea crithmifolia W. et K. populations. J Essential Oil Res., 2000; 12(1): 53-58.

19. Németh É, Essential oil composition of species in the genus Achillea. J Essential Oil Res., 2005; 17(5): 501-512.

20. Németh É, Achillea species used medicinally in Hungary. Israel J Plant Sci., 2010; 58: 279-289.

21. Pîrvu L, Sha'at F, Păvăloiu R, Udeanu DI, Albu B, Studies on Acinos alpinus L.: polyphenols and terpenoids compounds profile, antimicrobial activity, antioxidant effect and release experiments on the ethanol and propylene glycol extracts. Farmacia, 2019; 67(6): 1025-1033.

22. Pljevljakušić D, Ristić M, Šavikin K, Screening of yarrow (Achillea millefolium agg.) populations in Serbia for yield components and essential oil composition. Lekovite Sirovine, 2017; 37: 25-32.

23. Popovici MP, Vlase L, Oniga I, Tămaș M, HPLC analysis on polyphenolic compounds from Achillea species. Farmacia, 2007; 55(3): 353-357.

24. Popovici MP, Pârvu AE, Oniga I, Toiu A, Tămaş M, Benedec D, Effects of two Achillea species tinctures on experimental acute inflamation. Farmacia, 2008; 56(1): 15-23.

25. Popovici MP, Comparative pharmacobotanical study of some Achillea species from the spontaneous flora of Romania. PhD Thesis, „Iuliu Hațieganu” University of Medicine and Pharmacy Cluj-Napoca, 2009; 110, (available in Romanian).

26. Raal A, Orav A, Arak E, Essential oil content and composition in commercial Achillea millefolium L. herbs from different countries. J Essential Oil Bearing Plants, 2013; 15(1): 22-31.

27. Rahimmalek M, Sayed Tabatabaei BE, Arzani A, Etemadi N, Assessment of genetic diversity among and within Achillea species using amplified fragment length polymorphism (AFLP). Biochem System Ecol., 2009; 37(4): 354-361.

28. Sârbu I, Ștefan N, Oprea A, Vascular plants of Romania. Ed. „Victor B Victor”, 2013; 796-804, (available in Romanian). 
29. SPSS Inc. SPSS Statistics for Windows, Version 17.0. Chicago: SPSS Inc., 2008.

30. Tămaş M, Popovici MP, Oniga I, Coldea Gh, Infraspecific chemical taxa of Achillea distans Waldst. $E t$ Kit. from the Rodnei Mountains (Eastern Carpathians) Romania. Planta Medica, 2009; 75: 932.

31. Tetenyi $P$, Infraspecific chemical taxa of medicinal plants. Akad Kiado, Chemical Publishing Co Inc; $1^{\text {st }}$ edition, Budapest, 1970; 121-122.

32. Toncer O, Basbag S, Karaman S, Diraz E, Basbag M, Chemical composition of the essential oils of Achillea species, growin wild in Turkey. Int J Agric Biol., 2010; 12(4): 527-553.

33. Varga E, Fülöp I, Farczádi L, Croitoru MD, Polyphenolic determination from medicinal plants used in veterinary medicine by an UHPLC-LCMS/MS method. Farmacia, 2020, 68(6): 1129-1135.
34. Weiss RF, Fintelmann V, Herbal Medicine. $2^{\text {nd }}$ Ed. G. Thieme Verl. Stuttgart-New-York, 2000.

35. Wichtl M, Herbal Drugs. Medpharm CRC Press, Stuttgart, 1994; 342-345.

36. Yener I, Yilmaz MA, Olmez OT, Akdeniz M, Tekin F, Hasimi N, Alkan MH, Ozturk M, Ertas A, A detailed biological and chemical investigation of 16 Achillea species'essential oils via chemometric approach. Chem Biodiv., 2020; 10.1002/cbdv.201900484: 1-15.

37. *** Romanian Pharmacopoeia, ed. VIII, Supplement 1, Aetheroleum Millefolii. Medical Publishing House, Bucharest, 1968.

38. *** Romanian Pharmacopoeia, ed. X, Millefolii flos, Medical Publishing House, Bucharest, 1993.

39. *** European Pharmacopoeia, $9^{\text {th }}$, Yarrow-Millefolii herba. Council of Europe, 2016; 1564-1565. 